\title{
A new species of lizard genus Enyalius (Squamata, Leiosauridae) from the highlands of Chapada Diamantina, state of Bahia, Brazil, with a key to species
}

Miguel Trefaut Rodrigues ${ }^{1}$, Marco Antonio de Freitas ${ }^{2}$, Thais Figueiredo Santos Silva², and Carolina Elena Viña Bertolotto ${ }^{3}$

1 Departamento de Zoologia, Instituto de Biociências, Universidade de São Paulo. Caixa Postal 11.461, 05422-970, São Paulo, SP, Brazil.

2 Programa de Pós-Graduação em Zoologia, Universidade Estadual Santa Cruz. Rodovia Ilhéus/Itabuna Km 16, 45.650-000, Ilhéus, BA, Brazil.

${ }^{3}$ Departamento de Genética e Biologia Evolutiva, Instituto de Biociências, Universidade de São Paulo, and Faculdade de Medicina Veterinária, Universidade Santo Amaro, São Paulo, SP, Brazil.

\begin{abstract}
A new species of lizard genus Enyalius (Squamata, Leiosauridae) from the highlands of Chapada Diamantina, state of Bahia, Brazil, with a key to species. A new species of lizard genus Enyalius is described from Fazenda Caraibas, municipality of Mucugê, state of Bahia, northeastern Brazil, in the northern portion of the Serra do Espinhaço. It is characterized by an almost straight canthal ridge, a distinctive enlarged subocular, ventral scales and infradigital lamellae smooth, tail length varying between 2.02-2.18 times snout-vent length, 54-63 vertebral scales between occiput and base of tail, 144-167 paravertebral scales between occiput and base of tail, 44-47 transverse rows of ventrals between posterior level of forelimbs and anterior level of hindlimbs, 52-66 scales at mid-body between middle of venter and crest, 17-18 and 25-28 infradigital lamellae, respectively under Finger IV and Toe IV, 23-27 scales along dorsal surface of tibia, and 33-40 gular scales between mental and collar. The new species is sexually dichromatic with males being brightly colored with a series of six very conspicuous transverse wide black dorsal bands on body separated by deep orange light areas and females dull colored with a pattern of irregular dark or light brown longitudinal stripes. The new species was obtained at Serra do Sincorá, state of Bahia, Brazil, in low, thin, and dense semidecidual forests situated around $1000 \mathrm{~m}$ altitude, near the headwaters of the Rio Paraguaçu. Character distribution in Enyalius is discussed, the presently recognized subspecies of Enyalius catenatus are elevated to full species status and a key to the current species of Enyalius is presented.
\end{abstract}

Keywords: Squamata, Leiosauridae, Enyalius erythroceneus sp. nov., Chapada Diamantina, Brazil. 


\section{Introduction}

The arboreal to subarboreal species of the lizard genus Enyalius are restricted to predominantly forested areas in Brazil. Currently, six species are admitted, two of them polytypic: $E$. bilineatus, E. brasiliensis (with two subspecies: E. b. brasiliensis and E. b. boulengeri), E. catenatus (with three subspecies: E. c. catenatus, E. c. bibroni, and E. c. pictus), E. iheringii, E. leechii, and E. perditus (Jackson 1978). Except for E. leechii, which is restricted to Amazonia, all other forms of Enyalius occur along the remaining Atlantic Forest of eastern Brazil extending formerly from Rio Grande do Norte to Rio Grande do Sul, in forested habitats in central Brazil, in scattered patches of favorable habitats along the eastern mountain ridge of Serra do Espinhaço or in the semiarid Caatingas. These lizards are one of the most characteristic elements of the lizard fauna of the Atlantic Forest where most species are found. The striking color polymorphism, sexual dichromatism, ontogenetic color variation, and color change present in the extra-Amazonian forms of Enyalius were responsible for the nomenclatural chaos that characterized the early taxonomic history of the genus (Etheridge 1969). It was only after Etheridge's revision (1969) that the forms of Enyalius were adequately diagnosed and described. He examined material from all European and North American collections, recognized eight entities and gave them full species status. Later, Jackson (1978) recognized the distinctiveness of the forms recognized by Etheridge but ranked catenatus, bibroni, and pictus as subspecies of E. catenatus, and brasiliensis and boulengeri as subspecies of $E$. brasiliensis. In the same paper he also described Enyalius perditus, the last species to be described in the genus. In his study, based predominantly on material from Brazilian collections, he studied the geographic variation and distribution of the entities he recognized and hypothesized on their evolution and speciation. Since then Jackson's (1978) scheme has been almost uncritically adopted. The exceptions refer to one of the catenatus subspecies (bibroni) that has been considered without comment as a full species (Rodrigues 1991, Freire 1996, BorgesNojosa and Caramaschi 2004, SBH 2005), or to all other subspecies that Frost et al. (2001), adopting a conservative view, considered full species as well. Nevertheless, although admittedly variable, none of the new material of Enyalius subsequently obtained was considered sufficiently distinct to recognize new species.

In 2005 we obtained six specimens of Enyalius in isolated forested habitats near $1000 \mathrm{~m}$ altitude, in the northern portion of the Serra do Espinhaço (Chapada Diamantina), state of Bahia, northeastern Brazil. As they differ strikingly from all other known species of Enyalius in color pattern and several other characters, they are herein described as a new species.

\section{Material and Methods}

Snout-vent length (SVL) and tail length (TL) were measured to the nearest $\mathrm{mm}$ with a rule; scale counts of all examined specimens (Appendix I) were taken with the aid of a stereomicroscope. Scale counts and scale nomenclature are according to Jackson (1978), except for ventral scales counted between the posterior level of the forelimbs and the anterior level of the hindlimbs. Comparative material examined was selected to sample character variation in Enyalius in order to complement the diagnosis of the new species. For this reason we selected localities representing extremes of variation or distribution, oriented by Jackson (1978), without concern for sexual dimorphism. All data were taken from preserved specimens now housed at Museu de Zoologia da Universidade de São Paulo collection (MZUSP).

\section{Species Description}

Enyalius erythroceneus sp. nov.

(Figures 1-3)

Holotype - MZUSP 95420, an adult male 
from Fazenda Caraibas (1309'49', $\mathrm{s}$, 41 $\left.{ }^{\circ} 24^{\prime} 19^{\prime \prime} \mathrm{W}\right)$, district of Cascavel, municipality of Mucugê, Serra do Espinhaço (Chapada Diamantina), state of Bahia, northeastern Brazil, collected by Marco Antonio de Freitas and Thais
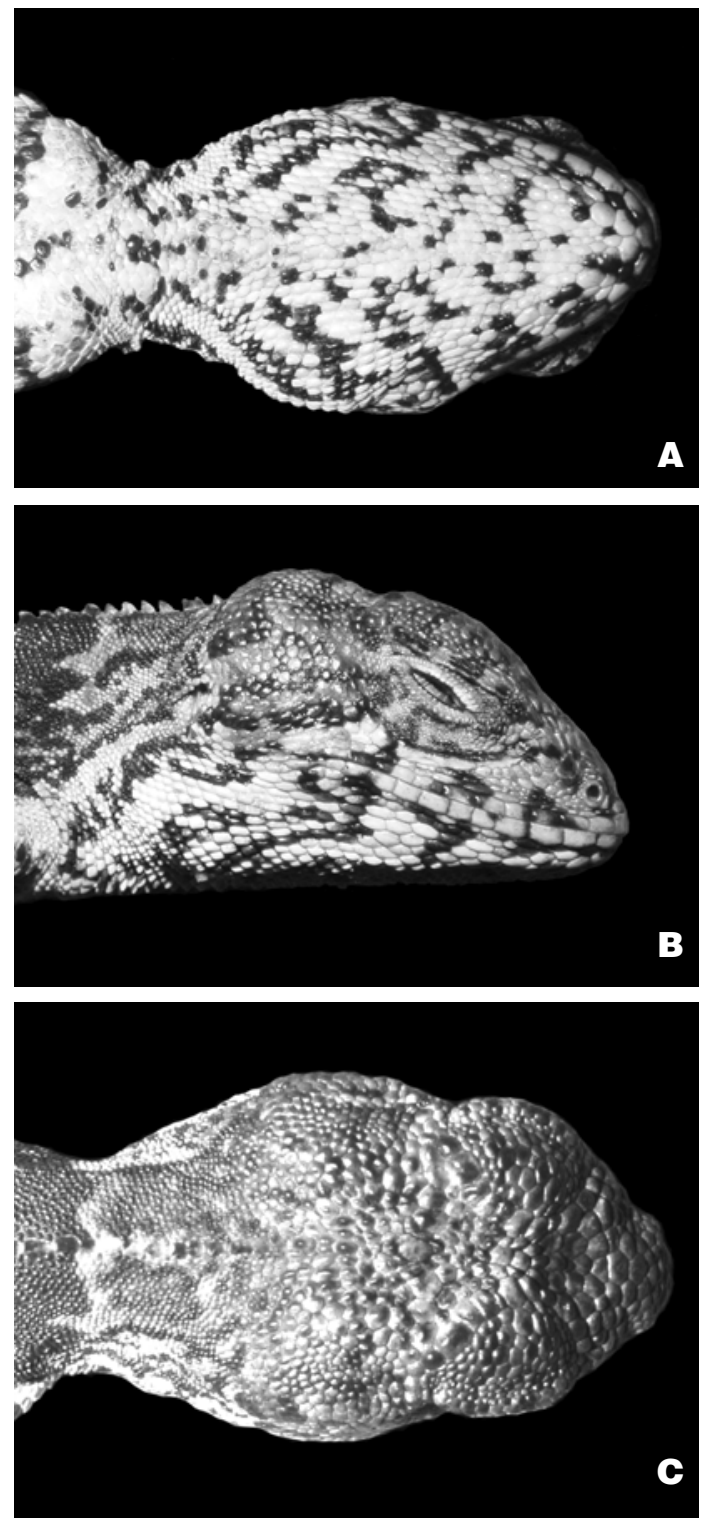

Figure 1. Ventral (A), lateral (B), and dorsal (C) views of head of the holotype of Enyalius erythroceneus sp. nov.
Figueiredo Santos Silva on 8 December 2005, field number MTR 11627.

Paratypes - MZUSP 95417, 95421, females, collected between 8 and 30 December 2005; MZUSP 95416, 95418, 95419, males, collected between 8 and 30 December 2005, all other data as for the holotype.

Etymology - from the Greek "erythros" meaning reddish and "keneon" meaning flank, a reference to the conspicuous deep reddishorange flank of males of the new species.

Diagnosis - A medium sized species of Enyalius (maximum SVL 90mm), characterized by an almost straight canthal ridge, a distinctive enlarged subocular, ventral scales and infradigital lamellae smooth, TL varying between 2.022.18 times SVL, 54-63 vertebral, and 144-167

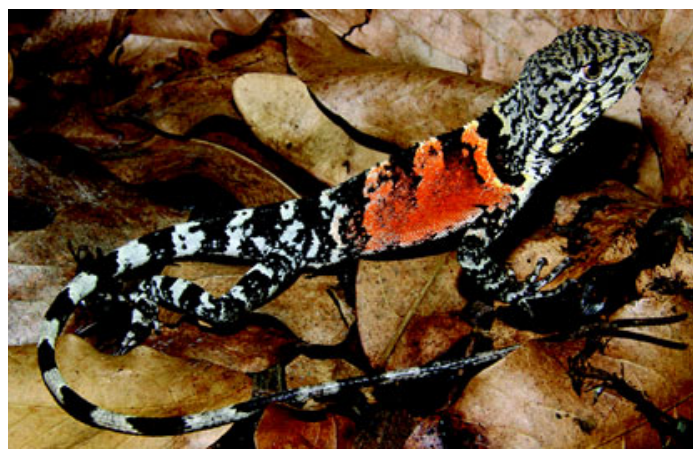

Figure 2 - Enyalius erythroceneus sp. nov., holotype, male (MZUSP 95420)

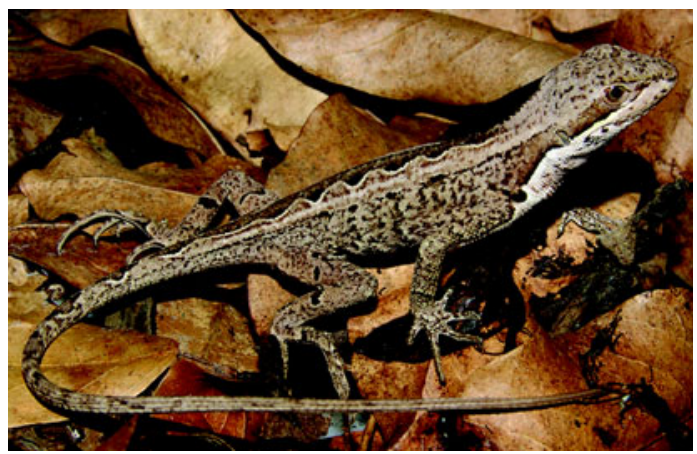

Figure 3 - Enyalius erythroceneus sp. nov., paratype, female (MZUSP 95421). 
paravertebral scales between the occiput and base of tail, 44-47 ventrals between posterior level of forelimbs and anterior level of hindlimbs, 52-66 scales at midbody between middle of venter and vertebral crest, 17-18 and 25-28 infradigital lamellae respectively under Finger IV and Toe IV, 23-27 scales along dorsal surface of tibia, and 33-40 gular scales between mental and collar. The new species is sexually dimorphic and can be distinguished from all known other species of Enyalius by the color pattern. Males have a series of six very conspicuous transverse wide black dorsal bands on body separated by deep orange areas, the anterior ones expanding onto the flank. Interspaces between posterior body bands grayish-green. Ventral parts of body and tail white, with an irregular black reticulum; central part of throat orange. Head with a dark brown to black reticulum alternating with lighter tan areas. Dorsal part of the limbs grayish-green with transverse dark brown bands, ventral parts of limbs identical to venter in color. Tail with a series of transverse dark bands with grayishgreen interspaces. Females have a longitudinal dorsal dark brown stripe extending from nape to first third of tail bordered by a series of lighter granules. A lateral brown stripe, dorsally and ventrally bordered by dark brown, extends from eye to base of tail. This last stripe is more conspicuous anteriorly, expanding dorsally before the upper arm and becoming diffuse posteriorly. Lower areas of lateral face of the head, nasals, supralabials, loreal region and lower part of tympanum creamy white. Venter and tail are light brown in females with two irregular ventrolateral dark brown stripes in the posterior two thirds of the venter; central part of throat with an irregular chevron shaped dark brown to black mark. Limbs and tail of females dark brown above, lighter ventrally, irregularly mottled with black.

Description of the holotype - Rostral wider than high, contacting posteriorly three small and transversally elongate scales. Dorsal head scales irregular in size and shape, rhomboid, juxta- posed, smooth; 16 scales between rostral and occipital. Supraorbital semicircles well defined with scales identical to other dorsal head scales, and separated at the midline by 2-3 scales. Most supraoculars enlarged, smooth, those closer to the supraorbital semicircles wider than long, becoming smaller and somewhat granular near the supraciliar border; 8 irregular series of supraoculars between supraorbital semicircles and superciliary border. Largest supraoculars about the same size of some of the scales of the supraorbital semicircles. Interparietal small with the pineal eye in the center, slightly longer than wide, approximately as large as the adjacent parietals; a minimum of 4 scales between interparietal and supraorbital semicircles. Occipitals mostly convex, large, tubercular, smooth, juxtaposed, smaller than interparietal and grading progressively into the dorsals. Nasal small, convex; nostril in center of nasal, laterally oriented, and occupying most of the scale. Nasal separated from supralabials by 1-2 elongate scales, dorsally emarginated by two supranasals and posteriorly by small granules. Canthal ridge distinct, straight, with two overlapping enlarged scales bridging most of the distance between supraciliaries and nasal. First (posterior) canthal largest, angulose; second one rounded, separated from the nasal by a distance similar to its size, which is covered by granular scales. Two rows of 9-10 elongate slightly imbricate to juxtaposed supraciliaries, the dorsal one with smaller scales and in contact with supraoculars. Loreal scales convex, juxtaposed, smooth, highly variable in size; largest ones just below the canthal area, smallest ones near the labial border. Preocular and subocular distinctively enlarged, much longer than wide, keeled along their upper margin, followed posteriorly by a series of much smaller scales forming an arc bordering the orbit. A series of distinctively enlarged palpebrals bordering upper and lower eyelid, rest of ocular region covered with granules. Eight enlarged and roughly rectangular supralabials, smooth, longer than high, separated from the loreals by a series of elongate granular scales 
and from the subocular by 1-2 rows of slightly enlarged scales. Temporals mostly rounded, smooth, almost flat, juxtaposed, with about the same size, smaller than larger supraoculars. Scales of the supratemporal arcade not distinctively differentiated from upper temporals but clearly distinctive from adjacent occipitals which are much smaller. Eleven infralabials, higher than the supralabials, otherwise similar to them. Ear opening ovoid, anterodorsally to posterodorsally oriented, tympanum slightly recessed; anterior margin of ear covered by pointed granules similar in size to the temporals, posterior border with much smaller granules, similar to those of the lateral surface of the neck.

Mental small, subtriangular, as long as wide or slightly wider than long, smaller than rostral. Two to three enlarged pairs of postmentals in diverging rows. The postmentals form a distinctive series of anteriorly enlarged scales that gradually merge into gulars. Anteriorly they are separated from the infralabials by a series of much smaller scales. Gular scales convex, smooth, juxtaposed, slightly rounded and small anteriorly, becoming progressively larger, conical, pointed, and elongate in the central area of the gular fold; posterior of the extensible part of the gular fold the gular scales become abruptly much larger, rounded, smooth, flat and imbricate towards the collar fold. Extensible central area of gular region with minute granules in the interspaces. Thirty five gular scales between mental and collar.

A middorsal crest of enlarged vertebral scales, more pronounced anteriorly, extends from occipital region to the first third of the tail. Dorsal and lateral nuchal scales granular, small, rounded, convex. A prehumeral fold continuous with collar. Dorsal and flank scales much smaller than those on the crest, slightly enlarged, slightly imbricate, slightly keeled and rounded near the crest, grading laterally into smaller, convex, juxtaposed and longitudinally elongate or rounded granules larger than those on the neck. Ventral scales several times larger than the dorsals, slightly smaller than the crest scales, smooth, imbricate, rounded posteriorly, varying in shape from cycloid (anteriorly) to wider than long, almost rectangular (posteriorly). Fifty four enlarged vertebral scales between the occipital and posterior level of the thigh; 163 paravertebral scales between occipital and posterior level of thigh; 124 scales around midbody; and 45 irregularly transverse rows of ventrals between the posterior level of the fore limb and the anterior level of the hind limb. Tail long, 2.17 times snout-vent length, slightly compressed at its base. Scales on tail increase gradually in size from the base of the tail where they are small, rounded, slightly keeled and imbricate, to strongly imbricate, large and longitudinally elongate towards its extremity. Ventral scales arranged in regular segments with four to five dorsal and three ventral scales per segment.

Scales on dorsal parts of forelimbs much larger than the adjacent dorsals, slightly smaller than the crest scales, slightly keeled and imbricate; ventral parts with smooth scales, varying in size from rather large (similar in size to those on dorsal surfaces) to small convex and juxtaposed granules. Ventral part of thigh with enlarged, smooth, rhomboidal, and slightly imbricate scales; dorsal part with a few slightly keeled and imbricate scales decreasing gradually in size scales towards the posterior part of the thigh where they are much smaller, granular, and juxtaposed. Dorsal part of tibia covered with enlarged, keeled and imbricate scales, smaller than those on the ventral part of the thigh; ventral part with scales of approximately the same size, smooth, imbricate. Twenty seven scale rows along the dorsal part of tibia between the posterior part of knee and the level of foot articulation. Scales on dorsal surfaces of carpus and tarsus similar in size, imbricate, smooth on carpus, keeled on tarsus; palmar and plantar surfaces with juxtaposed granules. Infradigital lamellae smooth, entire, with a median longitudinal groove dividing the 3-4 distal lamellae of each digit; 18 and 28 infradigital lamellae respectively under the Finger IV and Toe IV.

Hemipenis partially everted, showing a series of calices near the base of the organ. 
Color in life of the male - Dorsal part of the head in males with a dark brown to black reticulum alternating with lighter tan areas. Lateral face of the head is similar : loreal region is light brown, preocular and subocular are mostly white, there is an alternation of irregular black and white spots on the supralabials, and the temporal area has the same variegated pattern as the dorsal part of the head. The back and the posterior part of the neck are crossed by six very conspicuous transverse, wide, irregular, black bands. The first reaches the inferior level of the insertion of forelimb and is the most evident. The second band is situated between the forelimbs and does not reach the limb-insertion; third, fourth and fifth bands are diagonally oriented and converge slightly towards the posterior part of the body; the third is roughly placed at midbody and is restricted to the dorsal part of the flanks; fourth and fifth reach the venter; the sixth is placed between hindlimbs. Twelve similar bands are present on the tail. An extensive orange area resulting from the fusion of orange areas across cross bands extends along the flanks between the posterior border of first the black cross-band to the anterior border of fourth dark band. Areas between cross-bands on rest of the body and tail are grayish-green. Ventral parts of body and tail white with an irregular black reticulum. Central part of throat orange. Dorsal part of the limbs with an irregular pattern of dark brown to black transverse bands under a grayish-green background, ventral parts like those of venter and underside of the tail.

Measures of holotype - snout-vent length 90mm; tail length $195 \mathrm{~mm}$; head length 49mm; tibia lengh 20mm; hind limb length 66mm.

Karyotype - a preliminary analysis of the karyotype of Enyalius erythroceneus reveals a diploid number of 46 chromosomes (22 macro and 24 microchromosomes) instead of 36 (12 macro and 24 micro) or 38 (14 macro and 24 micro) present in all other Enyalius known (Bertolotto et al. 2005).
Variation - Maximum SVL for males and females is $90 \mathrm{~mm}$ and $70 \mathrm{~mm}$, respectively. TL varied respectively in males in females from 2.04-2.18 and 2.02-2.07 times SVL. No sexual differences were found in scale counts; range, mean and standard error are in Table 1 . Number of supralabials varied between 8-9 in the paratypes, as do the number of scales (3-6) marginating the rostral scale. Sexual color dichromatism is evident. All males are identical to the holotype except for the intensity of the orange flank coloration which is not so evident in the juveniles. Females are dark to light brown dorsally. They have a longitudinal dorsal dark brown stripe extending from nape to the first third of tail bordered by a series of light granules. In one specimen (MZUSP 95417) its borders are straight, in the other female they are undulating and the stripe was probably formed due to fusion of a series of rhomboidal longitudinal blotches which are still isolated on the tail. A lateral brown band, dorsally and ventrally bordered by dark brown extends from the eye to the base of the tail. It is more conspicuous anteriorly where it crosses the tympanum and expands dorsally at prehumeral level, becoming diffuse on the posterior part of the flank. Lower areas of the lateral face of the head, nasal, supralabials, loreal region and lower part of tympanum creamy white. Venter and tail light brown with an irregular wide chevron-shaped dark brown to black mark in the central part of the throat, and two irregular ventrolateral dark brown stripes on the posterior two thirds of the venter. Limbs and tail dark brown above, lighter ventrally, irregularly mottled with black.

Comparisons - Table 1 shows character distribution for all forms of Enyalius presently recognized, except for Enyalius brasiliensis boulengeri. Considering that differences between boulengeri and the nominal form of brasiliensis are mostly due to TL/SVL ratio and hind limb length and in most specimens examined the tail was incomplete we treat them together as one taxon. 


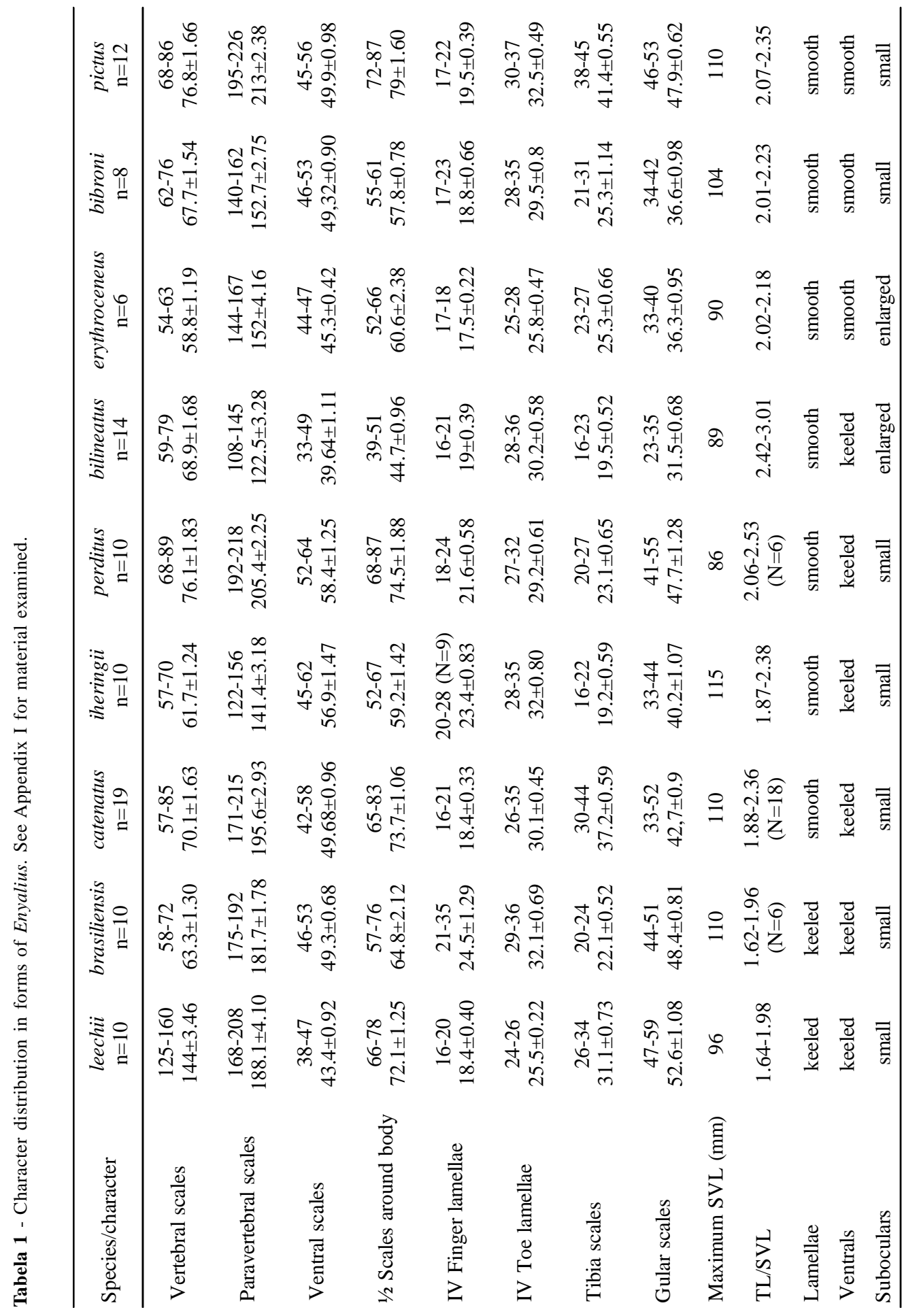


Enyalius erythroceneus and bilineatus can be separated from all other forms of Enyalius by their distinctive and enlarged subocular. Nevertheless, they strongly differ in number of paravertebral scales, scales around midbody, number of fourth toe lamellae, number of scales along dorsal part of tibia, TL/SVL ratio, color pattern, and ornamentation of the ventral scales, smooth in E. erythroceneus, strongly keeled in E. bilineatus (Table 1). The only other congeners sharing the smooth condition of ventrals with Enyalius erythroceneus, are bibroni and pictus. Enyalius erythroceneus differs strikingly from pictus in the number of vertebral and paravertebral scales, $1 / 2$ number of scales around midbody, number of fourth toe lamellae, number of scales along dorsal part of tibia and of gular scales. In all these characters there is very slight or no overlap in scales counts (Table 1 ). The color pattern although superficially similar is very different between the two species. Males of pictus have a series of 5 enlarged dorsal transverse bands on body reminiscent of the 6 bands of erythroceneus, but never have the deep reddish orange color on the flanks that characterizes the new species. For comparison Figure 4 shows a reproduction of the plate which accompanied the original description of Agama picta by Wied (1823). In most characters, bibroni is the form of Enyalius most similar to Enyalius erythroceneus. Nevertheless, they are very different, showing only marginal overlap in number of vertebral scales and number of fourth toe lamellae, presence of an enlarged subocular in erythroceneus (absent in bibroni) and in color pattern. Males of bibroni are uniformly creamy white or diversely mottled with a reticulate pattern dorsally and laterally very different from that observed in erythroceneus. Female color pattern is more similar and the two species share the presence of faint longitudinal ventral stripes ( 2 in erythroceneus, 3 or more in bibroni) but the lines of small paravertebral white spots present in bibroni are absent in erythroceneus. Species of Enyalius with keeled ventrals are leechii, brasiliensis, catenatus, iheringii, perditus and bilineatus. Enyalius leechii and Enyalius brasiliensis (E. b. boulengeri included) are the only forms of Enyalius with strongly keeled infradigital lamellae. They additionally differ from E. erythroceneus (data in parenthesis) by presenting keeled ventrals (smooth), small suboculars (enlarged), smaller TL/SVL ratio, number of gular scales, and number of paravertebral scales (Table 1). Enyalius erythroceneus additionally differs from $E$. leechii by the extreme reduction (almost absence) of the dorsal crest in the latter. Enyalius catenatus, iheringii, and perditus, like erythroceneus have smooth infradigital lamellae, but have keeled ventral scales and no enlarged subocular. Additional to striking differences in color pattern (males are green in the three species) there is no overlap in scale counts between erythroceneus and perditus in number of vertebral scales, between erythroceneus, catenatus and perditus in number of paravertebral scales, between erythroceneus and perditus in number of ventral scales, between erythroceneus and perditus in half the number of scales around midbody, between erythroceneus and iheringii in number of fourth finger and fourth toe lamellae, between erythroceneus, iheringii, and catenatus in number of scales along dorsal part of the tibia, and finally between erythroceneus and perditus in number of gular scales (Table 1).

The anterior portion of canthal ridge is clearly curved toward midline in catenatus, pictus, and bibroni and is straight or slightly curved in bilineatus, perditus, iheringii, brasiliensis, and leechii. The canthal ridge of $E$. erythroceneus is closer to that of second group of species.

Although it has generally been admitted that Enyalius has reversed sexual dimorphism with females being larger than males (Jackson 1978, Teixeira et al. 2005, Vitt et al. 1996) we do not feel confident to extend comparisons in body size between erythroceneus and the other forms of Enyalius. In the type series males are larger than females but our sample is too small to decide further beyond this point. 
Habitat and distribution - All specimens were collected at Fazenda Caraibas, a 5.200 hectares farm situated on a relatively flat upland plateau situated around $1.100 \mathrm{~m}$ altitude on the west side of the escarpments of Serra do Sincorá. The Serra do Sincorá is a section of Chapada Diamantina, the local name to the northern segment of the mountain ridge referred to as Serra do Espinhaço. The highest elevations of Serra do Sincorá form an extensive ridge emerging from the plateau and reaching up $1620 \mathrm{~m}$. The entire region is located in the municipality of Mucugê, district of Cascavel near Vila de Caraíba, a small village with about 40 houses. Fazenda Caraibas is situated west of the highest escarpments of Serra do Sincorá. The eastern border of Fazenda Caraibas reaches the western escarpment of Serra do Sincorá where it contacts the edge of the Parque Nacional da Chapada Diamantina (PNCD). The escarpment of Serra do Sincorá is dominated by the typical vegetation of "campos rupestres" (rocky meadows, see Giulietti and Pirani 1988) where quartzitic sandy soils and rocky outcrops are characteristic. The drainage runs towards north and consists of small streams associated with the headwaters of the Rio Paraguaçu. Vegetation at Fazenda Caraibas includes several types of Cerrado like vegetation, semidecidual seasonal forest (carrasco, locally), and gallery forest along the river valleys. In the eastern part of Fazenda Caraibas, near the escarpment of Serra do Sincorá, the relief is more pronounced and dominated by extensive areas of white sandy soils covered by an open cerrado like vegetation, mixed with that of campos rupestres. A new Eurolophosaurus related to E. nanuzae and an undescribed Mabuya were abundant in this area but no specimens of Enyalius were collected. The western part of Fazenda Caraibas is dominated by an extensive plateau covered by a semideciduous forest. This forest ("carrasco" locally) characterized by the abundance of Myrtaceae, was very dense and formed by relatively low and thin trees of about 4-5 meters high and with $5-10 \mathrm{~cm}$ diameter, exceptionally with some scattered emergent trees reaching $15 \mathrm{~m}$ high (Figure 5). It was in this forest that all specimens of Enyalius where obtained during a deforestation process aiming to introduce agriculture in the plateau area. Specimens were obtained manually, walking behind a tractor during the deforestation process. The 23 specimens of Enyalius observed (only six were allowed to be collected) resulted from the deforestation of 2,5 circular plots with $1 \mathrm{~km}$ diameter, 80 hectares each, totaling 200 hectares. In the same area 44 specimens of Mabuya, 9 of Ameiva ameiva, and 8 of Eurolophosaurus were observed. Although an important part of the semidecidual forests occurring on the plateaus of the headwaters of the Rio Paraguaçu are being destroyed, a 2.500ha area of Fazenda Caraibas in contact with PNCD has been declared protected. Presently it forms a faunal corridor of 300m wide contacting the small APP (permanent protected area) Barragem do Apertado, near the Apertado reservoir in the Rio Paraguaçu where these forests are still present and where E. erythroceneus likely occur.

\section{Discussion}

Two clearly distinct morphological groups appear to exist in Enyalius. In the first Enyalius leechii stands alone by it distinctiveness. It lacks sexual dichromatism, color polymorphism or ontogenetic color variation, has minute and strongly keeled dorsal head scales and is characterized by a vestigial or absent dorsal crest. The strongly keeled condition of the infradigital lamellae of Enyalius leechii are only shared with Enyalius brasiliensis, in all other species lamellae are smooth. Like brasiliensis almost all other Enyalius are characterized by strong color dichromatism, color polymorphism and ontogenetic color variation in males. Enyalius bilineatus is the only exception because although extremely polymorphic, sexual dichromatism is absent (Etheridge 1969, Jackson 1978). Adult males are uniformly or predominantly light green in brasiliensis, catenatus, 


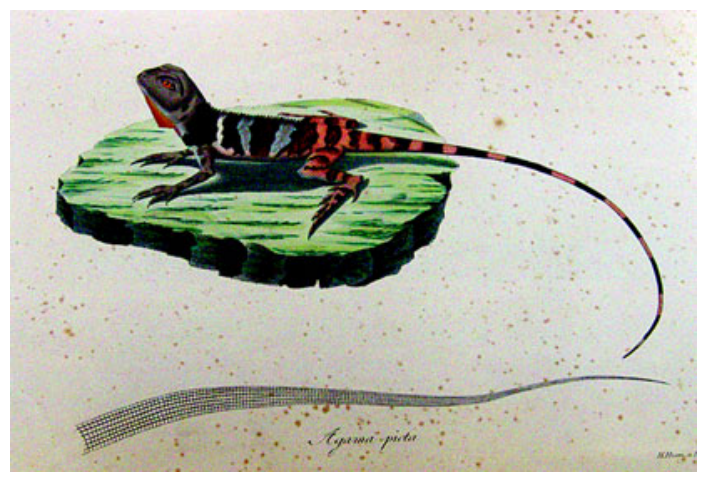

Figure 4 - Original color plate of Agama picta Wied, 1825.

iheringii, perditus whereas their young males are almost uniformly brown. Adult males of these species also have the ability to change color becoming suddenly dark brown; females are highly variable in color but have a variable series of dorsal dark spots arranged longitudinally with or without a pair of dorsolateral light stripes. Although sexual dichromatism is also present in bibroni, pictus, and erythroceneus, males of these species are never uniformly green: they are whitish or spotted to various degrees in bibroni or olive brown with a conspicuous series of enlarged transverse bands in erythroceneus and pictus.

It was the striking difference in color pattern between bibroni and catenatus that lead the first author to informally attribute to the former full species status after they where collected a few kilometers apart in the region of Morro do Chapéu in state of Bahia. Figures 6 and 7 exhibit number of paravertebral scales and number of scales along the dorsal surface of the tibia in forms of Enyalius and shows that differences between catenatus and bibroni are accentuated. Although there is broad overlap in scale counts between catenatus and pictus, differences in color pattern are also striking. In the extensive area between the Rio Jequitinhonha and the Rio Doce where pictus occurs males are never uniformly green but, with some variation, correspond all to the pattern of Figure 4. From

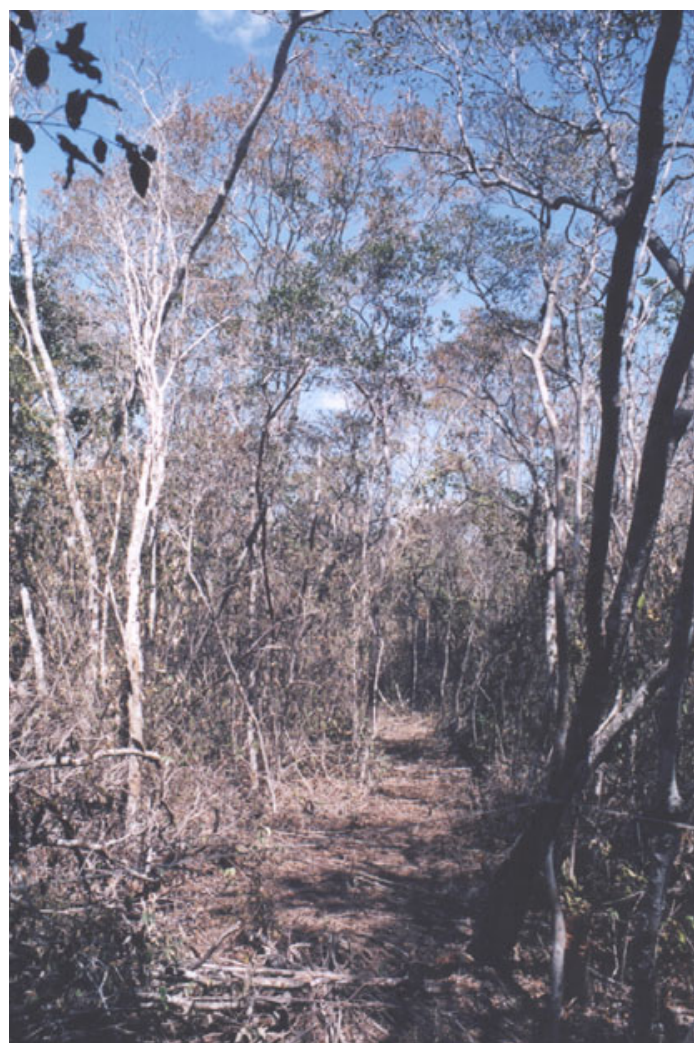

Figure 5 - Habitat of Enyalius erythroceneus sp. nov.: semideciduous forest at Fazenda Caraibas, Mucugê, state of Bahia, northeastern Brazil.

the northern bank of the Rio Jequitinhonha towards the north, catenatus occurs and males are uniformly green. Based on scale counts and differences in color pattern mentioned above, on differences in ornamentation of the ventral scales (Table 1), and on geographic distribution, we think that there is no more bases to recognize subspecies for Enyalius catenatus as proposed by Jackson (1978). We formally propose here to elevate bibroni, catenatus, and pictus to full species status.

Based on our present knowledge it is impossible to interpret confidently the color pattern variation, because several conflicting hypothesis were proposed to explain relationships between 


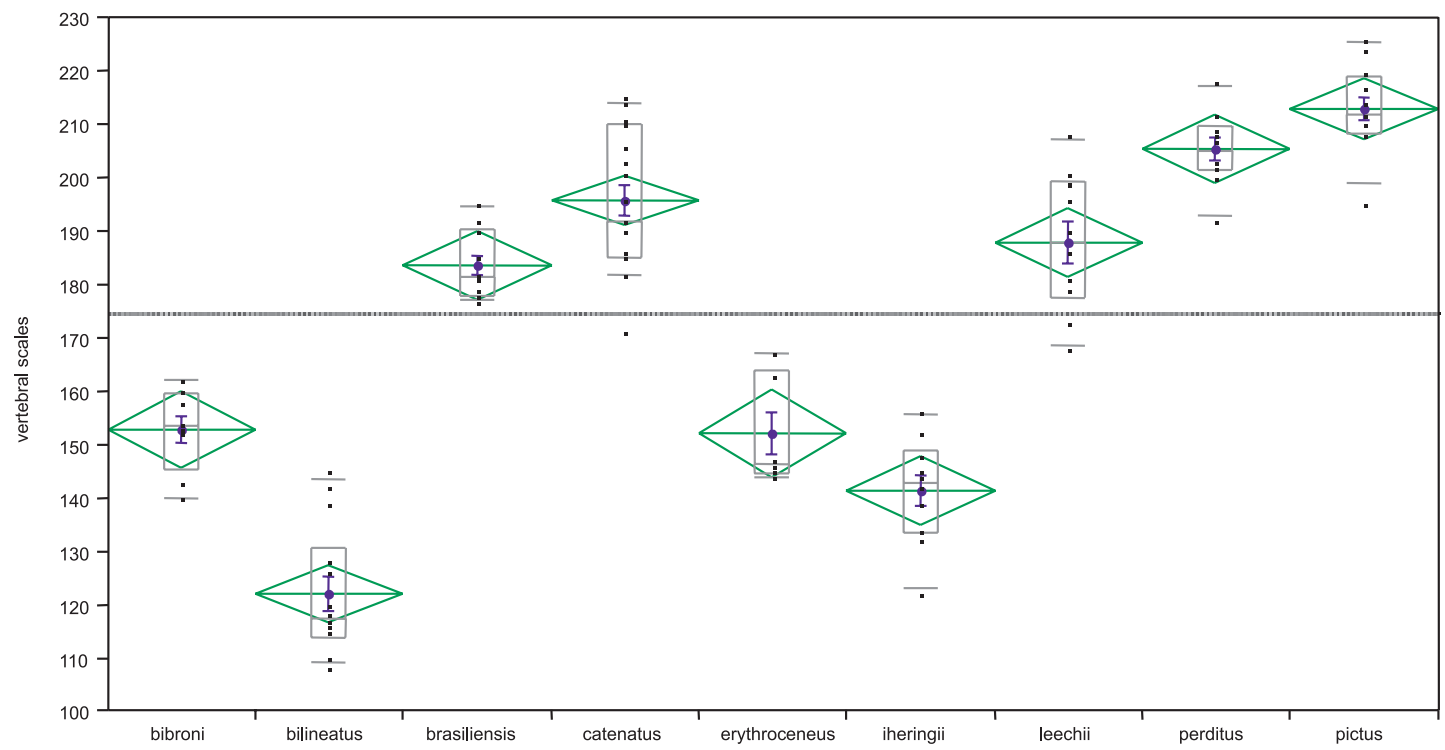

Figure 6 - Number of paravertebral scales in Enyalius. Mean with error bars, quantile boxes and diamonds are showed.

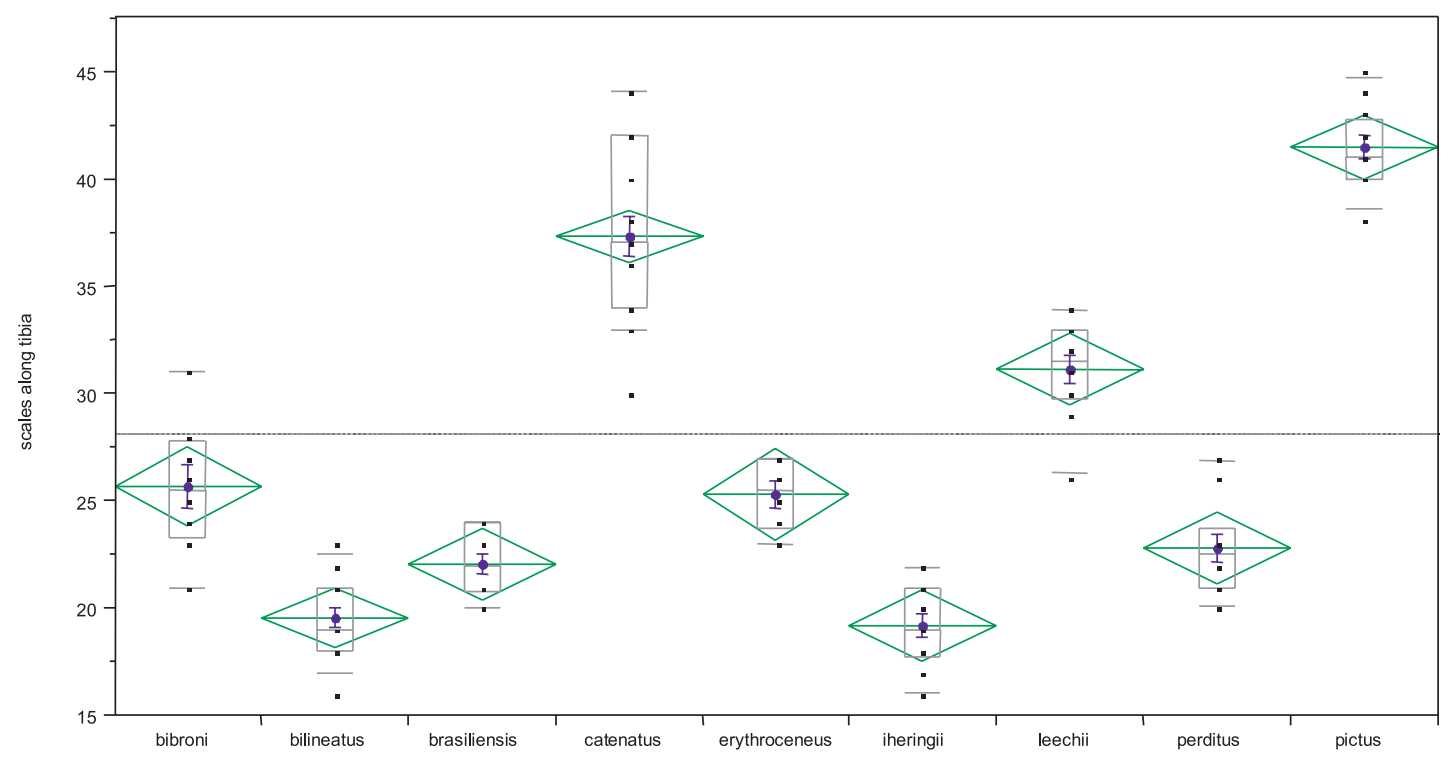

Figure 7 - Number of scales along dorsal face of tibia in species of Enyalius. Mean with error bars, quantile boxes and diamonds are showed.

species of Enyalius. Based on the absence of tail autotomy, presence of smooth infradigital lamellae, absence of sexual dichromatism, conspicuousness of vertebral crest and orientation of keels in ventral scales Etheridge (1969) considered Enyalius bilineatus the most basal 
species of the Enyalius radiation. None of the three hypotheses of relationships proposed by Jackson agree with this. Contrarily, Jackson's (1978) preferred phylogeny places Enyalius bilineatus as the most derived species in the genus, considering it possibly as a bibroni or pictus derivative. Instead he considered Enyalius brasiliensis as the basal species to this radiation having Enyalius leechii as its closest relative. Jackson (1978) further admitted that $E$. perditus and E. iheringii were sequentially derived from brasiliensis and basal to his "catenatus” grouping. One of Jackson's alternative hypotheses was based on color pattern and assembled all species with green males referred to above. Frost et al. (2001), the first analysis in the modern phylogenetic sense, was based on morphological and molecular data but genetic sampling was restricted to E. bilineatus and E. leechii. They considered Enyalius as monophyletic, having $E$. bilineatus as the basal species and (iheringii (perditus ((boulengeri, leechii, brasiliensis) catenatus, and (pictus and bibronii)))) sequentially derived. Alternative relationships between perditus and boulengerileechii-brasiliensis and between leechii and brasiliensis were also supported (Frost et al., 2001). Actually, it was the nested position of leechii with the forms of brasiliensis that lead them to adopt the full species status for the subspecies recognized by Jackson (1978).

Considering the highly variable external morphology and color polymorphism affecting Enyalius species and the conflicting phylogenetic hypotheses for the genus we do not feel confident to discuss the relationships of Enyalius erythroceneus. For the time being, we prefer only to say that, although very dissimilar, Enyalius erythroceneus and Enyalius bilineatus share the presence of an enlarged subocular scale, and that Enyalius eythroceneus resembles Enyalius bibroni in general external morphology. We hope that a phylogenetic hypothesis assembling new molecular data and extensive taxa sampling, now underway, could illuminate further these questions.
As the identification of Enyalius has been particularly problematic with the available keys, the following one is presented as an additional aid to their identification. As we think that when new material becomes available, the subspecies of Enyalius brasiliensis (sensu Jackson 1978) should be the subject of more detailed studies, its subspecies are not included in the present key.

\section{A key to the species of Enyalius}

1. All infradigital lamellae distinctively keeled 2

Infradigital lamellae smooth 3

2. A vertebral crest of enlarged scales absent or inconspicuous; more than 100 paravertebral scales; all head scales with distinctive, high, and longitudinally oriented keels; postsimphysials absent; sexual dichromatism absent, males identical to females, never green leechii

A distinctive crest of enlarged vertebral scales; less than 80 paravertebral scales; head scales smooth or with low keels; postsimphysials present, sexual dichromatism present, males green brasiliensis

3. A distinctive enlarged and elongate subocular present 4

Enlarged subocular absent, orbit bordered below by an arc of small and subequal scales. 5

4. Ventrals distinctively keeled, phyloid; canthus rostralis straight; tail longer than 2.4 times SVL bilineatus

Ventrals smooth, quadrangular; canthus rostralis slightly curved; tail shorter than 2.2 times SVL erythroceneus sp. nov.

5. Ventrals smooth or slightly keeled, males never uniformly green 6 Ventrals strongly keeled, males uniformly green ..... 7 
6. Less than 170 paravertebral scales, less than 65 scales around midbody between middle of venter and crest; less than 35 scales along tibia; males creamy whitish or variedly spotted dorsally; venter with three faint longitudinal stripes

bibroni

More than 190 paravertebral scales, more than 70 scales around midbody between middle of venter and crest; more than 38 scales along dorsal surface of tibia; males olive brown with conspicuous enlarged transverse bands; venter immaculate ... pictus

7. Canthal ridge curved toward midline; more than 30 scales along dorsal surface of tibia, vertebral crest low, not well defined or interrupted near base of tail catenatus

Canthal ridge straight, less than 30 scales along dorsal surface of tibia, vertebral crest high, with very enlarged scales and well defined near base of tail 8

8. More than 180 paravertebral scales ..perditus Fewer than 150 paravertebral scales ... iheringii

\section{Acknowledgements}

We thank Fundação de Amparo à Pesquisa do Estado de São Paulo (FAPESP) and Conselho Nacional de Desenvolvimento Científico e Tecnológico (CNPq) for support, IBAMA for collection license (number 021/2005-NUFAU/ IBAMA/BA), Agroinvest Kayatani S/A, Mitsuru Origushi, and Eduardo Varejão for their valuable help in the field, and Hussam Zaher and Carolina Castro-Mello for access to specimens. Thanks are also due to Felipe Curcio and José Cassimiro.

\section{References}

Bertolotto, C. V. E., K. C. M. Pellegrino, M. T. Rodrigues, and Y. Y. Yassuda. 2005. Karyotype diversity among the species of the endemic Brazilian lizard genus Enyalius (Leiosauridae, Squamata). Pp. 151-152 in Abstracts of the $5^{\text {th }}$ World Congress of Herpetology, Stellenbosch.
Borges-Nojosa, D. M. and U. Caramaschi. 2004. Composição e análise comparativa da diversidade e afinidades biogeográficas dos lagartos e anfisbenídeos (Squamata) dos brejos nordestinos. Pp. 463-505 in I. R. Leal, M. Tabarelli, and J. M. C. Silva (eds.), Ecologia e Conservação da Caatinga. Editora Universitária da UFPE, Recife. 804pp.

Etheridge, R. 1969. A review of the iguanid lizard genus Enyalius. Bulletin of the British Museum (Natural History) Zoology 18: 233-260.

Freire, E. M. X. 1996. Estudo ecológico e zoogeográfico sobre a fauna de lagartos (Sauria) das dunas de Natal, Rio Grande do Norte, e da restinga de Ponta de Campina, Cabedelo, Paraíba, Brasil. Revista Brasileira de Zoologia 13: 903-921.

Frost, D. R., R. Etheridge, D. Janies, and T. Titus. 2001. Total evidence, sequence alignment, evolution of polychrotid lizards, and a reclassification of the Iguanidae (Squamata, Iguania). American Museum Novitates 3343: 1-38.

Giulietti, A. M. and J. R. Pirani. 1988. Patterns of geographic distribution of some plant species from the Espinhaço range, Minas Gerais and Bahia, Brazil. Pp. 39-69 in P. E. Vanzolini and W. R. Heyer (eds.), Proceedings of a Workshop on Neotropical Distribution Patterns. Academia Brasileira de Ciências, Rio de Janeiro.

Jackson, J. F. 1978. Differentiation in the genera Enyalius and Strobilurus (Iguanidae): implications for Pleistocene climatic changes in eastern Brazil. Arquivos de Zoologia, São Paulo 30: 1-79.

Rodrigues, M. T. 1991. Os lagartos da floresta atlântica brasileira: distribuição atual e pretérita e suas implicações para estudos futuros. Pp. 404-410 in II Simpósio sobre os Ecossistemas da Costa Sul e Sudeste Brasileira: Estrutura, Função e Manejo. Volume 1. Academia de Ciências do Estado de São Paulo.

SBH. 2005. Lista de espécies de répteis do Brasil. Sociedade Brasileira de Herpetologia. Available at http:// www2.sbherpetologia.org.br/checklist/repteis.htm. Captured on 28 December 2005.

Teixeira, R. L., K. Roldi and D. Vrcibradic. 2005. Ecological comparisons between the sympatric lizards Enyalius bilineatus and Enyalius brasiliensis (Iguanidae, Leiosaurinae) from an Atlantic Rain-Forest area in southeastern Brazil. Journal of Herpetology 39: 504-509.

Vitt, L. J., T. C. Ávila-Pires and P. Zani.1996. Observations on the ecology of the rare Amazonian lizard Enyalius leechii (Polychrotidae). Herpetological Natural History 4: 77-82.

Wied Neuwied, M. 1823. Abbildungen zur Naturgeschichte Brasiliens (Recueil de planches coloreìes d'animaux du Breìsil). Weimar, 1822-31. Plate of Agama picta.

Wied Neuwied, M. 1825. Beiträge zur naturgeschichte von Brazilien. Weimar Vol. 1. xxii + 614 pp. 


\section{Appendix I - Comparative Material Examined}

Enyalius bibroni - BAHIA: Morro do Chapéu: MZUSP 55945-55947. CEARÁ: Mulungú: MZUSP 87589; Pacoti: MZUSP 88592. PARAÍBA: Areia: MZUSP 66105. PERNAMBUCO: Serra Negra: MZUSP 68908. PIAUÍ: Parque Nacional da Serra da Capivara: MZUSP 92454.

Enyalius bilineatus - DISTRITO FEDERAL: Brasília: MZUSP 88707. ESPÍRITO SANTO: Santa Tereza: MZUSP 39520, 95424. GOIÁS: UHE Corumbá IV: MZUSP 95425. MINAS GERAIS: Conservatório: MZUSP 5566; Juiz de Fora: MZUSP 42778; Nova Ponte: 7880978811; Ouro Preto: 95178-95180, 95184; Rio Preto: MZUSP 10410.

Enyalius brasiliensis - ESPÍRITO SANTO: Itá: 4277; Santa Tereza: MZUSP 8825, 17453, 17454, 39528, 39535, 39537, 95426. RIO DE JANEIRO: Rio de Janeiro: 10247, 10251.

Enyalius catenatus - BAHIA: Una: MZUSP 95400-95415; 34 Km E Morro do Chapéu: MZUSP 55936. PERNAMBUCO: Serra dos Cavalos: MZUSP 66130.

Enyalius iheringii - PARANÁ: Morretes:
MZUSP 67703; Marumbi: 39513. RIO GRANDE DO SUL: Torres: MZUSP 33380. SANTA CATARINA: Corupá: MZUSP 42743; São Bento do Sul: MZUSP 67029, 67212. SÃO PAULO: Rio de Una, Estação Biológica da Juréia Itatins: MZUSP 55930; Paranapiacaba: 94834; BiritibaMirim MZUSP 95422, 95423.

Enyalius leechii - MATO GROSSO: Apiacás: MZUSP 81877, 81678, 81680; Aripuanã: MZUSP 81536; Cláudia: MZUSP 81722, 81779, 81780, 81782, 81783. PARÁ: Juruá: Rio Xingú: MZUSP 67399.

Enyalius perditus - ESPÍRITO SANTO: Parque Nacional do Caparaó: MZUSP 9542795430. MINAS GERAIS: Alfenas: MZUSP 94043, 94044; Lambari: MZUSP 94040-94042. SÃO PAULO: Estação Biológica de Boracéia: MZUSP 74905.

Enyalius pictus - BAHIA: Reserva Biológica Pau Brasil: MZUSP 66155-66161; Cumuruxatiba: MZUSP 59185; Reserva Veracruz Florestal: MZUSP 91486,91487. ESPÍRITO SANTO: Conceição da Barra: MZUSP 39539. 